J. Soc. Cosmet. Chem. Jpn.

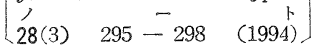

\title{
頭の臭いに関する研究
}

宔田正男，駒木亮一，伊藤芳和，新井及ち代，庭瀬英明

鐘紡株式会社 化粧品研究所†

\section{Investigation of the Odor Evolved from Human Hair}

\author{
Masao Kubota, Ryoichi Komaki, Yoshikazu Ito, \\ Mitiyo Arai and Hideaki Niwase \\ Cosmetics Laboratory, KANEBO LTD. $\uparrow$
}

\begin{abstract}
It has been known empirically that the odor evolved from human hair and scalp is different from the odor from body or foot.

We tried to identified the volatile compounds evolved from human hair and scalp using headspace sampling method and extraction by acetone.

By the headspace method, over eighty of compounds were detected and almost thirty subsequently identified. The latter belong to various chemical classes such as alkanes, alkenes, alcohols, aldehydes, and acids. We tried to reconstitute of the odor according to the result of analysis and using the sense of perfumers.

Moreover, the changing of volatile compounds and increasing of scalp resident bacteriars during three days were investigated.
\end{abstract}

\section{1. 緒言}

日本人は比較的体臭が少ないと言われてきた。 しかし食生活の変化や生活環境の変化，また清潔 に対する意識が高くなってきた事より，多くの人 が『自分の臭い』に関し不安を感じはじめてい る。

体臭関する研究は，今までに多くの研究者に よってなされて招り，脇の下や足の臭いについて は，との原因となる成分についても詳細に検討さ れている。しかし，人の毛髪和よび頭皮から揮発 する臭い，すなわち『頭の臭い』に関しては報告 はいまだに少ない。また官能的にも，頭の臭い は，腋臭や足臭とは異なった臭いに感じられる。

† $\overline{\mathbf{T}} 250$ 神奈川県小田原市寿町 5-3-28 ; 5-3-28 Kotobukicho Odawara-shi Kanagawa 250 Japan
そこで頭の臭いの成分の検討, 頭皮常在菌の検 討，季た頭の臭いの再現を試みたので報告する。

\section{2. 実 験 方 法}

\section{1 頭の臭い分析}

パネラーに健康な青年男子 5 名（24〜38才）を 用い，頭の臭いについてへッドスペースガス分析 特よび溶剂抽出により検討を行った。

\section{2 頭部へッドスペースガス分析}

サンプル捕集：無香料ンャンプーで洗髮後, 3 日間 $(0,2 ， 4 ， 8 ， 12 ， 24 ， 32,48 ， 72 \mathrm{hr})$ 経時 に打いて頭の臭いのへッドスペースガスを捕集剤 飞Tenax TA $(0.08 \mathrm{~g})$ を用い, 捕集した。活性炭 にて脱臭された空内にて，パネラーの頭部にテフ ロン製のバッグを被せ，バッグ内のへッドスペー スガスを吸入速度 $0.5 \ell / \mathrm{min}$. にて 30 分間捕集し 
た。捕集管に吸着させたサンプルは Thermal Desorption Cold Trap Injector(chrompack 社製) によって GCキャピラリーカラム中に注入 乙分析を行った。

\section{3 溶剂抽出}

無香料シャンプーで洗髪 3 日後, 頭部を Acetone $3 l$ で洗い流し, 減压濃縮後得られた Wax の酸性部分をカラム処理して得た 2 フラクション をメチルェステル化し GC 拈よび GC-MS にて 分析を行った。

\section{4 頭皮常在菌の測定}

無香料シャンプーで洗髪後 3 日間 $(0,2 ， 4$,

$8,12,24,32,48,56 \mathrm{hr}$ ) 経時に和いて, パネ
ラーの頭頂部より直径 $1 \mathrm{~cm}$ の円筒形チューブを 用いスクラブ法により皮膚常在菌を採取した(0.1 $\%$ Tween80 75mmol NaPB (Ph 7.0))。

培地は $0.5 \%$ Tween 80 入り BHI を用い平板 培湌し，菌数を測定した。

\section{3. 結果}

\section{1 頭の臭い分析: ヘッドスペースガス分析}

Fig. -1 無香料シャンプーにて洗髪 72時間後の 頭の臭いの GC チャート (TIC) を示す。この解 析結果より頭の臭いの原因となっていると思われ る Hydrocarbon, Acid, Aldehyde など25の 成分を同定した。

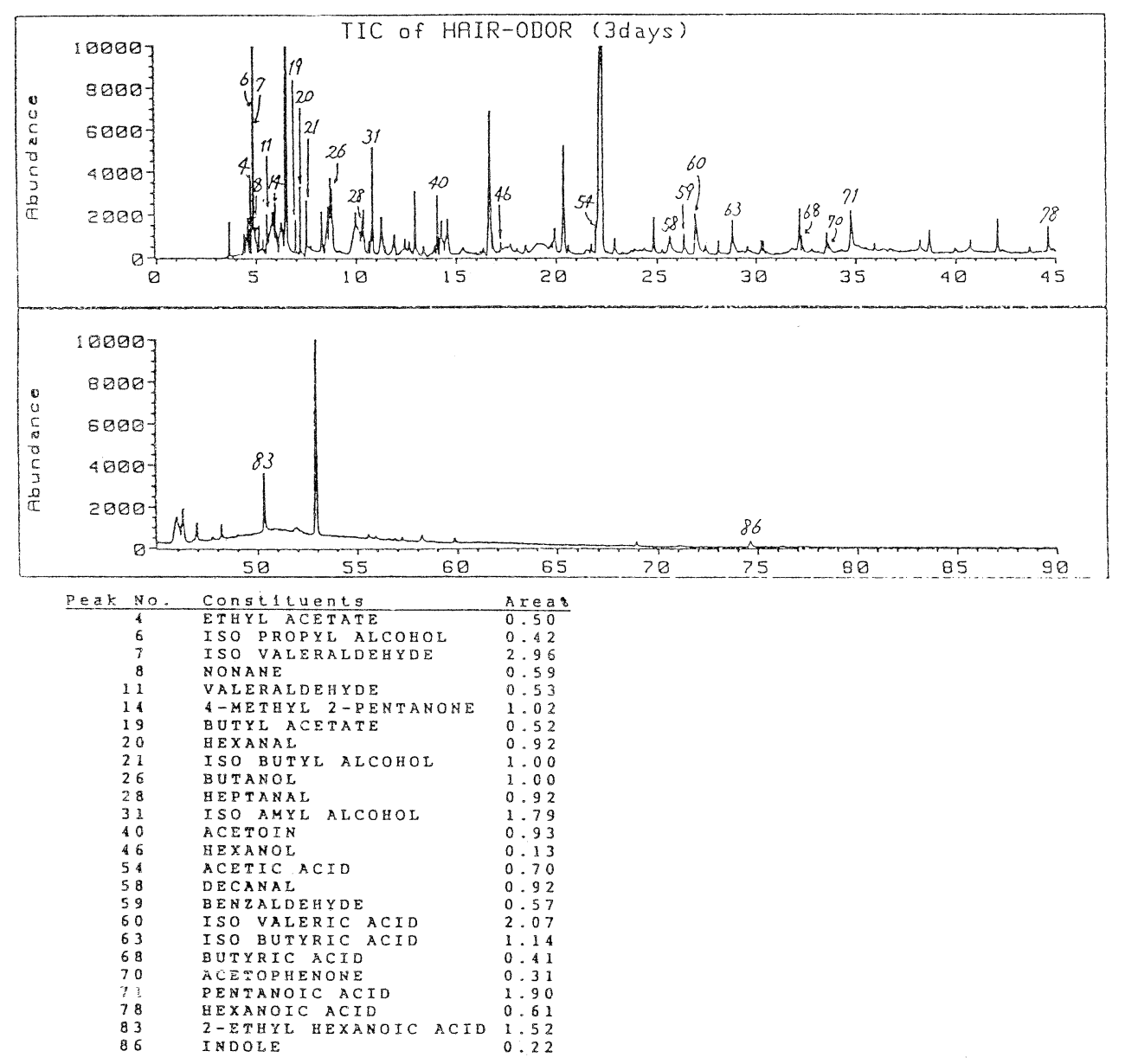

Fih.-1 洗髪 3 日後（72時間後）の頭の臭いヘッドスペースガス分析結果 


\section{2 頭の臭い分析: 溶剤抽出物分析}

頭髮のアセトン抽出物より $\mathrm{C}_{4} \sim \mathrm{C}_{22}$ までの脂肪 酸が同定され, Tetradecanoic acid, Hexadecanoic acidの比率が特に高かった。

\section{3 頭皮常在菌の測定}

好気性菌 St.epidermidis, St.capitis, 嫌気性菌 Propionibacterium 属が検出された。また, 経時 に㧧いて頭皮常在菌の増加が観察され, 特に好気 性菌は，嫌気性菌より顕著な增加を示した。

\section{4. 考察}

表皮の脂肪酸は，皮脂腺から生じるトリグリセ ライドやワックスエステルが分解されて生じた り，皮膚常在菌による作用で生じると考㝋られて いる。頭髪の溶剤抽出物にはC14, C16の長鎖脂肪 酸が多く存在し，また皮膚常在菌の測定に拈い て, 経時で頭皮常在菌の増加が観察された。頭の 臭いが次第に強くなっていく原因の 1 つとして, 頭皮に存在する長鎖脂肪酸が，増加する頭皮常在 菌の作用で臭いの強い短鎖の脂肪酸に分解される 事が考光られる。

『頭の臭い』を含兑体臭に関して，その臭いも
のととなる。いわゆる Key-oder と呼ばれる成 分について考察すると, 例光ば足臭では Iso valeric acid が Key-oder 之示唆され, 腋卓に関 しては，Key-oderは単一成分ではなく，一般的 飞炭素数の多い（5以上）低級脂肪酸が類似して いるとの報告がある。頭の臭いに関しても, Keyoder は単一成分ではなく, Valeraldehyde, Heptanal 等の軽い刺激臭を持つアルデヒド類, そして Iso valeric acid, Iso butyric acid, Pentanoic acid, Hexanoic acid, 等の低級脂 肪酸, そして Indole 等の香気物質が混在して一 つの臭いを作っていると考兄らる。

さらに，皮膚常在菌の構成を検討してみると， 体の皮膚では St. epidermidis が大半を構成する のに対し，頭部ではSt.capitis がその大半を構成 して和り, 常在菌の構成の違いが, 頭の臭いが腋 臭や足臭とは異なった臭いに感じられる原因の1 つになっているのではないかと思われる。そこで， 分析結果を基に，『頭の臭い』の再現を試み，更 に調香師による実際の頭の臭いとの比較評価を加 光，頭の臭いの再現を行った（Table-1）。

Table-1『頭の臭い』再現処方

INGREDIENTS

\begin{tabular}{rrrr}
\hline \hline ETHEL ACETATE & 1.54 & ANETHOL & 0.25 \\
ISO-PROPYL ALCOHOL & 1.29 & GERANYL ACETONE & 5.78 \\
NONANE & 1.81 & 2-PHENYLETHYL ALCOHOL & 1.11 \\
4-METHYL 2-PENTANONE & 3.13 & INDOLE & 0.68 \\
BUTYL ACETATE & 1.60 & ISO-VALERALDEHYDE & 9.10 \\
ISO-BUTYL ALCOHOL & 3.07 & VARELALDEHYDE & 1.63 \\
BUTANOL & 3.07 & HEXANOL & 2.83 \\
ISO-AMYL ALCOHOL & 5.50 & HEPTANAL & 1.91 \\
LIMONENE & 7.34 & ACETIC ACID & 2.15 \\
ETHYL LACTATS & 0.86 & DECANAL & 2.83 \\
METHYL HEPTENONE & 12.97 & BENZALDEHYDE & 1.75 \\
HXANOL & 0.40 & PROPIONIC ACID & 6.36 \\
LINALOOL & 0.92 & ISO-BUTYRIC ACID & 3.50 \\
MENTHOL & 1.60 & BUTYRIC ACID & 1.26 \\
ACETOPHENONE & 0.95 & PENTANOIC ACID & 5.84 \\
MENZYL ACETATE & 1.60 & HEXANOIC ACID & 1.87 \\
SALICYLATE & 1.35 & 2-ETHYL HEXANOIC ACID & 4.67
\end{tabular}

TOTAL 100.00 


\section{参考文 献}

1）神田不仁広他, 粧技誌, 23 巻 3 号, 1989

2) Fujio Kanda, et al, 15th IFSDD International Congress Preprints Platfoam Presentations volume $3: 529-562,1988$
3）本好捷宏，フレグランスジャーナル，No.92, 1988

4) 小林真次, 日本細菌学雑誌, 45(4), 1990

5) Donald T. Downing, et al. The Journal of Investigative Dermatology, 62:244, 1973

6) Noel Goetz, et al, J. Soc. Cosmet. Chem., $39,1-13,1988$

(1994年5月2日受理) 